\title{
Failed angioembolization of a ruptured liver hemangioma complicated by iatrogenic injury of subclavian vein during catheter insertion
}

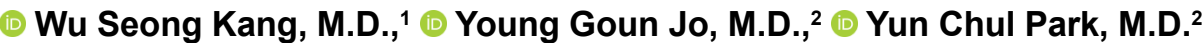

${ }^{1}$ Department of Trauma Surgery, Wonkwang University Hospital, Iksan-Korea

${ }^{2}$ Division of Trauma Surgery, Department of Surgery, Chonnam National University Hospital and Medical School, Gwangju-Korea

\begin{abstract}
In this study, we report a case of failed angioembolization of a ruptured liver hemangioma complicated by iatrogenic injury of the subclavian vein during catheter insertion. A 30-year-old woman experienced blunt trauma upon falling from her bed. Laceration of a seemingly preexisting hepatic hemangioma was diagnosed. No other injury was detected during a preoperative diagnostic workup. Subclavian vein catheterization was performed, followed by angioembolization to control bleeding due to the ruptured hemangioma.After angioembolization, the patient's systolic blood pressure and hemoglobin levels were $70 \mathrm{mmHg}$ and $5.3 \mathrm{~g} / \mathrm{dL}$, respectively. She underwent emergency laparotomy. During the surgery, a large volume of blood in the abdominal cavity due to profuse bleeding from the ruptured hemangioma was observed. Because of a hemothorax found on chest radiography, we performed thoracoscopy, which revealed a large volume of blood in the right thoracic cavity and perforation of the subclavian vein by the catheter. After the damage-control surgery, the patient recovered safely. In this case, ruptured liver hemangioma complicated by subclavian vein catheter-related injury was treated safely using damage-control surgery. The catheter-related injury could be identified and treated using thoracoscopy.
\end{abstract}

Keywords: Catheter; hemorrhage; injuries; liver; subclavian.

\section{INTRODUCTION}

For hemodynamically unstable trauma patients, central venous catheterization is used to achieve sufficient resuscitation. The subclavian vein is a common route used for the central line. However, central venous catheterization may cause complications ranging from mild to severe. ${ }^{[1]}$ Especially, mechanical complications of subclavian catheterization, such as hemothorax or pneumothorax, may aggravate other injuries in the acute stage of severe trauma, and these complications may result in deterioration of the clinical course.

In this study, we report a case of failed angioembolization of a ruptured liver hemangioma complicated by iatrogenic injury of the subclavian vein during catheter insertion.

\section{CASE REPORT}

A 30-year old woman was admitted to our emergency room (ER) with a referral from another hospital. She experienced blunt trauma upon falling from her bed and was injured by hitting a dumbbell on the floor at her home. Upon arrival, her systolic blood pressure (SBP) was $50 \mathrm{mmHg}$, and after crystalloid fluid resuscitation, her SBP increased immediately to $100 \mathrm{mmHg}$. Her initial blood hemoglobin was $8.8 \mathrm{~g} /$ $\mathrm{dL}$, and arterial blood gas analysis (AGBA) revealed a $\mathrm{pH}$ of 7.26. A computed tomography (CT) scan had already been performed at the previous hospital and hepatic hemangioma laceration ( $1.5 \mathrm{~cm}$ in segment 8 ) with perihepatic hemoperitoneum was diagnosed (Fig. Ia). The hemangioma appeared to have been preexisting. There was no abdominal tender-

Cite this article as: Kang WS, Jo YG, Park YC. Failed angioembolization of a ruptured liver hemangioma complicated by iatrogenic injury of subclavian vein during catheter insertion. Ulus Travma Acil Cerrahi Derg 2020;26:635-638.

Address for correspondence: Young Goun Jo, M.D.

42, Jebong-ro, Dong-gu, Gwangju, 61469, Korea Gwangju, South Korea

Tel: +82 62-220-6456 E-mail: thinkjo82@gmail.com

Ulus Travma Acil Cerrahi Derg 2020;26(4):635-638 DOI: 10.14744/tjtes.2019.04343 Submitted: 13.01.2019 Accepted: 05.08.2019 Online: 24.06.2020

Copyright 2020 Turkish Association of Trauma and Emergency Surgery 
ness on physical examination. No other injury was detected during a preoperative diagnostic workup. In the ER, subclavian vein catheterization was performed for effective resuscitation, and chest radiography was checked to identify the indwelling catheter and complications, such as pneumothorax and hemothorax (Fig. 2b). Subsequently, angioembolization successfully controlled the bleeding of the hemangioma laceration (Fig. Ib). After angioembolization, the patient was admitted to the intensive care unit (ICU). However, 30 minutes after the angioembolization, the patient's SBP and blood hemoglobin decreased to $70 \mathrm{mmHg}$ and $5.3 \mathrm{~g} / \mathrm{dL}$. Additionally, her abdomen was distended and a newly developed hemothorax was found on chest radiography (Fig. 2c). An emergency reoperation was immediately performed. After laparotomy, a large volume of blood in the abdominal cavity due to profuse bleeding from ruptured hemangioma was observed. Trocars were inserted into the right chest wall to identify the cause of the hemothorax. During thoracoscopy, a large volume of blood in the right thoracic cavity was seen and perforation
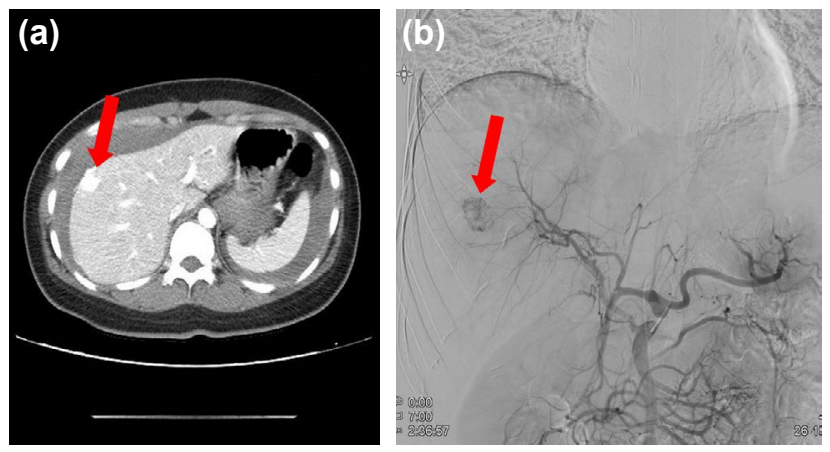

Figure 1. (a) Abdominal computed tomography scan showed ruptured hepatic hemangioma (red arrow) with hemoperitoneum. (b) Angiography showed hepatic hemangioma (red arrow).
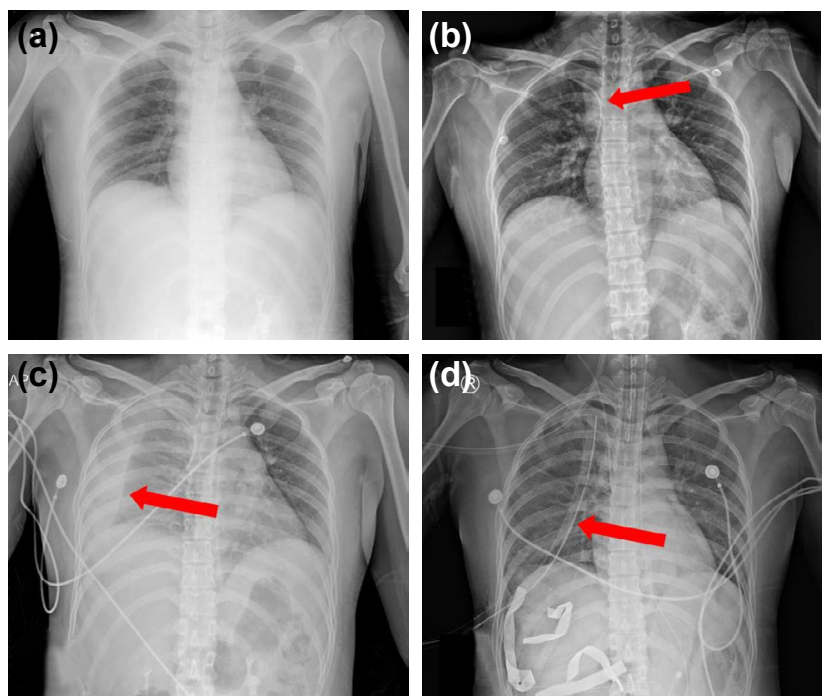

Figure 2. (a) Chest X-ray (CXR) at the time of admission. (b) CXR after right subclavian venous catheterization seemed to show catheter tip (red arrow) in normal position. (c) CXR after angioembolization showed hemothorax (red arrow). (d) CXR after the first operation with thoracoscopy showed an indwelling chest tube (red arrow). The right subclavian venous catheter was removed. of the subclavian vein by the catheter was found (Fig. 3). As the ongoing bleeding of the ruptured hemangioma was found, pad compression of the liver to control the bleeding was performed with temporary abdominal closure (Fig. 4). After the removal of the subclavian vein catheter, there was no bleeding from the subclavian vein. The injured subclavian vein remained without any additional suture or ligation. An additional catheter was inserted via the right internal jugular vein. A thoracostomy tube was also inserted into the right thoracic cavity via a trocar site (Fig. 2d). Transfusion of 16 units of packed red blood cells and eight units of fresh frozen plasma was performed during the operation. Two days after the first laparotomy, a second operation was performed, the pad was removed, and the patient's abdomen was closed. The chest tube was removed on postoperative day nine. The patient recovered well and was discharged on the postoperative day 12. patient's consent was obtained for this study.

\section{DISCUSSION}

In this era of damage-control laparotomy, damage control is regarded as the most effective strategy to treat coagulopathy and prevent a vicious cycle of the hemorrhagic shock. [2] Although the term "damage control" was first coined in 1993 by Rotondo et al., ${ }^{[3]}$ the concept of abbreviated surgery followed by a secondary definitive operation for major liver trauma was already tried in 1979. [4] Recently, perihepatic packing has been the most widely used and suc-

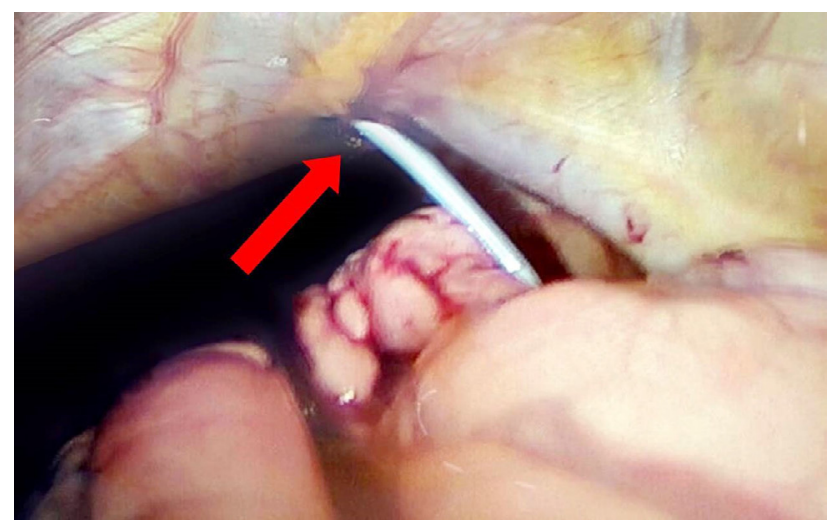

Figure 3. The red arrow is pointing to the catheter, which is seen protruding into the thoracic cavity via the venous wall, identified during thoracoscopy.
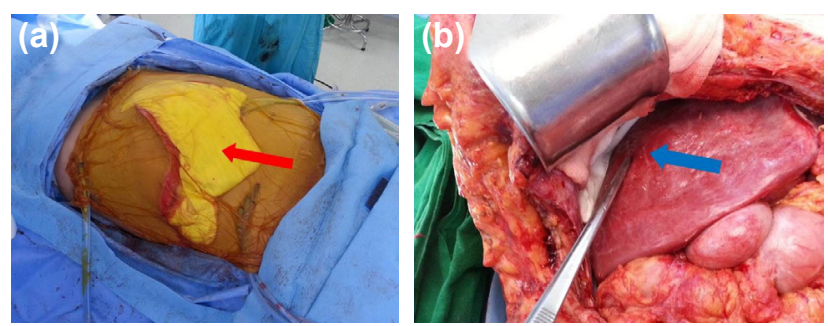

Figure 4. (a) Pad packing (red arrow) with temporary abdominal closure was performed in the first operation. (b) No bleeding from the ruptured hepatic hemangioma occurred during the second operation. 
cessful method for the surgical management of blunt hepatic trauma. ${ }^{[5]}$ In most cases, the cause of the uncontrolled hepatic hemorrhage is the trauma itself. In the present case, although the ruptured hemangioma was initially treated successfully using interventional radiology, failed angioembolization with the iatrogenic injury that arose from the subclavian vein catheter aggravated the coagulopathy. Damage-control laparotomy with hepatic pad packing was used to control bleeding because suture hemostasis or liver resection may cause additional bleeding in a patient with coagulopathy. It is a unique situation in that a lower-energy trauma-induced rupture of hepatic hemangioma. Additionally, the clinical deterioration that arises from the subclavian catheter injury was also uncommon. The initial chest radiography appeared completely normal and did not reveal a pneumothorax or hemothorax. Thoracoscopy, however, revealed the catheter tip penetrating into the thoracic cavity using the subclavian venous lumen, allowing transfused blood and fluid to accumulate in the thoracic cavity.

Mechanical complications (such as arterial puncture, hematoma, and pneumothorax) of central venous catheterization are reported to occur in $5 \%$ to $19 \%$ of patients, and infectious and thrombotic complications are reported to occur in $5 \%$ to $26 \%$ and $2 \%$ to $25 \%$ of patients, respectively. [I] The mechanical complications are reported to be similar to whether catheterization is performed using the internal jugular or the subclavian route. ${ }^{[l]}$ In the prospective randomized trial of subclavian vein catheterization by Mansfield et al.,, ${ }^{[6]}$ the complications included misplacement, arterial puncture, pneumothorax, and mediastinal hematoma. In another prospective randomized trial by Merrer et al., ${ }^{[]]}$no major hematoma or hemothorax occurred in the subclavian vein catheterization group. In a case report by Haaverstad et al.,. ${ }^{[8]}$ it was reported that a right subclavian catheter perforated the aorta, resulting in sudden cardiac tamponade. However, to our knowledge, there is no report similar to the present case. In the present case, thoracoscopy during the operation was performed to evaluate the hemothorax. If the thoracoscopy had not been done, it would have been difficult to identify the penetration of the catheter into the thoracic cavity.

Liver hemangiomas are the most common benign liver tumors and may grow up to $20 \mathrm{~cm} \cdot{ }^{[9]} \mathrm{In}$ autopsies, the incidence of liver hemangiomas is reported from $0.4 \%$ to $7.3 \%$. ${ }^{[9]}$ In a recent large retrospective cross-sectional study about the prevalence and clinical outcome of a hepatic hemangioma that analyzed 83,181 patient records, ${ }^{[10]}$ the prevalence of hepatic hemangioma was $2.5 \%$ and spontaneous bleeding occurred in only five patients $(0.47 \%)$. Additionally, all patients with spontaneous bleeding had a giant hemangioma $(>4 \mathrm{~cm}$ in diameter). ${ }^{[10]}$ In the present case, the size of the heman- gioma was only $1.5 \mathrm{~cm}$ and a low-energy injury was suspected because she had fallen from the bed. Because of the small size of the hemangioma in the present case, perihepatic pad packing without resection appeared to be sufficient treatment and no additional sign of bleeding was found after the second operation. In the literature, ${ }^{[9,10]}$ it was reported that arterial embolization and surgical resection are available for ruptured hemangiomas. However, to our knowledge, there is a lack of evidence regarding damage-control laparotomy for a ruptured hemangioma.

In conclusion, the subclavian vein catheter penetrated into the thoracic cavity via the subclavian venous wall, which contributed to the failure to correct the coagulopathy. The patient was successfully treated using damage-control surgery with thoracoscopy.

Informed Consent: Written informed consent was obtained from the patient for the publication of the case report and the accompanying images.

Peer-review: Internally peer-reviewed.

Conflict of Interest: None declared.

\section{REFERENCES}

1. McGee DC, Gould MK. Preventing complications of central venous catheterization. N Engl J Med 2003;348:1123-33. [CrossRef]

2. Ball CG. Damage control surgery. Curr Opin Crit Care 2015;21:538-43.

3. Rotondo MF, Schwab CW, McGonigal MD, Phillips GR 3rd, Fruchterman TM, Kauder DR, et al.'Damage control': an approach for improved survival in exsanguinating penetrating abdominal injury. J Trauma 1993;35:375-82; discussion 382-3. [CrossRef]

4. Calne RY, McMaster P, Pentlow BD. The treatment of major liver trauma by primary packing with transfer of the patient for definitive treatment. Br J Surg 1979;66:338-9. [CrossRef]

5. Kozar RA, Feliciano DV, Moore EE, Moore FA, Cocanour CS, West MA, et al. Western Trauma Association/critical decisions in trauma: operative management of adult blunt hepatic trauma. J Trauma 2011;71:1-5.

6. Mansfield PF, Hohn DC, Fornage BD, Gregurich MA, Ota DM. Complications and failures of subclavian-vein catheterization. $\mathrm{N}$ Engl J Med 1994;331:1735-8. [CrossRef]

7. Merrer J, De Jonghe B, Golliot F, Lefrant JY, Raffy B, Barre E, et al; French Catheter Study Group in Intensive Care. Complications of femoral and subclavian venous catheterization in critically ill patients: a randomized controlled trial. JAMA 2001;286:700-7. [CrossRef]

8. Haaverstad R, Latto PN, Vitale N. Right subclavian catheter perforation of the aorta due to an incorrect external landmark-guided insertion technique. CJEM 2007;9:43-5.

9. Donati M, Stavrou GA, Donati A, Oldhafer KJ. The risk of spontaneous rupture of liver hemangiomas: a critical review of the literature. J Hepatobiliary Pancreat Sci 2011;18:797-805. [CrossRef]

10. Mocchegiani F, Vincenzi P, Coletta M, Agostini A, Marzioni M, Baroni GS, et al. Prevalence and clinical outcome of hepatic haemangioma with specific reference to the risk of rupture: A large retrospective cross-sectional study. Dig Liver Dis 2016;48:309-14. [CrossRef] 


\section{OLGU SUNUMU - ÖZET}

\section{Kateter yerleştirilmesi sırasında subklavyen venin iyatrojenik yaralanması ile komplike olan rüptüre karaciğer hemanjiyomunun başarısız anjiyoembolizasyonu \\ Dr. Wu Seong Kang, ${ }^{1}$ Dr. Young Goun Jo, ${ }^{2}$ Dr. Yun Chul Park ${ }^{2}$}

${ }^{1}$ Wonkwang Üniversite Hastanesi, Travma Cerrahisi Kliniği, Iksan-Kore

${ }^{2}$ Chonnam Ulusal Üniversite Hastanesi ve Tıp Fakültesi, Cerrahi Anabilim Dalı, Travma Cerrahisi Bölümü, Gwangju-Kore

Biz kateter takılması sırasında subklavyen venin iyatrojenik yaralanması ile komplike rüptüre bir karaciğer hemanjiyomunun başarısız anjiyoembolizasyonu olgusunu sunuyoruz. Otuz yaşında bir kadın yatağından düştüğünde künt travmaya maruz kalmış. Önceden var olduğu görünen hepatik bir hemanjiyomun laserasyonu teşhis edildi. Ameliyat öncesi tanısal incelemeleri sırasında başka bir yaralanma tespit edilmedi. Subklavyen ven kateterizasyonu ve ardından rüptüre hemanjiyom nedeniyle oluşan kanamayı kontrol etmek için anjiyoembolizasyon yapıldı. Anjiyoembolizasyondan sonra hastanın sistolik kan basıncı ve hemoglobin düzeyi sırasıyla $70 \mathrm{mmHg}$ ve $5.3 \mathrm{~g} / \mathrm{dL}$ idi. Acil laparotomi yapıldı. Ameliyat sırasında, rüptüre hemanjiyomdan abondan kanama nedeniyle karın boşluğunda büyük miktarda kan gözlendi. Göğüs radyografisinde hemotoraks bulgusu nedeniyle uygulanan torakoskopi sağ toraks boşluğunda büyük miktarda kan olduğunu ve subklavyen venin kateter tarafından delinmiş olduğunu gösterdi. Hasar kontrol cerrahisinden sonra hasta güvenli bir şekilde iyileşti. Bu olguda, subklavyen ven kateteri ile ilişkili yaralanma ile komplike olan rüptüre karaciğer hemanjiyomu hasar kontrol cerrahisi ile güvenli bir şekilde tedavi edildi. Kateterle ilişkili yaralanma torakoskopi kullanılarak tanımlanabilir ve tedavi edilebilir.

Anahtar sözcükler: Kanama; karaciğer; kateter; subklavyen; yaralanma

Ulus Travma Acil Cerrahi Derg 2020;26(4):635-638 doi: 10.14744/tjtes.2019.04343 